Music
at the Turn
of Century 

California Studies in 19th-Century Music Joseph Kerman, General Editor

1. Between Romanticism and Modernism: Four Studies in the Music of the Later Nineteenth Century, by Carl Dahlhaus, translated by Mary Whittall

2. Brahms and the Principle of Developing Variation, by Walter Frisch

3. Music and Poetry: The Nineteenth Century and After, by Lawrence Kramer

4. The Beethoven Sketchbooks: History, Reconstruction, Inventory, by Douglas Johnson, Alan Tyson, and Robert Winter

5. Nineteenth-Century Music, by Carl Dahlhaus, translated by J. Bradford Robinson

6. Analyzing Opera: Verdi and Wagner, edited by Carolyn Abbate and Roger Parker

7. Music at the Turn of Century: A 19th-Century Music Reader, edited by Joseph Kerman 
A 19th-Century Music Reader Edited by Joseph Kerman 


\section{Music at the Turn of Century}

UNIVERSITY OF CALIFORNIA PRESS

Berkeley - Los Angeles • Oxford 
University of California Press

Berkeley and Los Angeles, California

University of California Press, Ltd.

Oxford, England

(C) 1990 by

The Regents of the University of Califormia

\section{Library of Congress Cataloging-in-Publication Data}

Music at the turn of century : a 19 th-century music reader / edited by Joseph Kerman.

p. $\quad \mathrm{cm} .-$ (California studies in 19 th century music ; 7)

ISBN 0-520-06854-8 (alk. paper). - ISBN 0-520-06855-6 (pbk. :

alk. paper)

1. Music-19th century-History and criticism. 2. Music-20th century -History and criticism. I. Kerman, Joseph, 1924-

II. 19 th century music. III. Series.

ML 196.M85 1990

$780^{\prime} .9^{\prime} 034-\mathrm{dc} 20$

CIP

MN

Printed in the United States of America

123456789

The paper used in this publication meets the minimum requirements of American National Standard for Information Sciences - Permanence of Paper for Printed Library Materials, ANSI Z39.48-1984. @ 